\title{
Хponuka in criber.
}

19 мая въ Һазани защитпл диссертацію на стешен доктора медициы асспстенты ири кафелрь шспхіатріи Казанскаго университета $\boldsymbol{b} . \boldsymbol{M}$. Воротьискій. оффидіальными онионентани были профф.: Н. А. Миславскій,

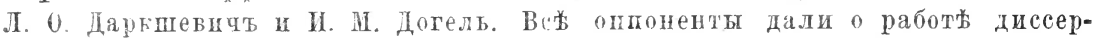
танта лестные отзывы п пожелали ему продолжать сз такимы же успь-

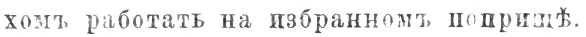

- Въ Іравит. Выетн. опубликовано мндніе Государственнаго Совтта

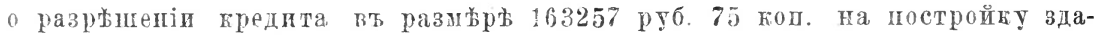
нія для Гродненской окружной Личебнищы для душевно-больныхь. Г. Ми-

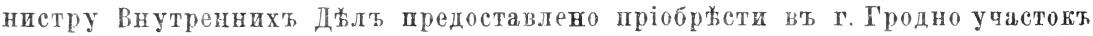

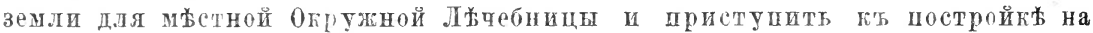
этом' участкт зданія для означеннаго льчебнаго заведенія. Газета с Волынь сообщаеть, что въ скоромь времени для выбора миста прибудеть вице-дрегторь Медицнскаго Департамента Малиновскій.

- Іравит. Вистн. сообщаетк, что закладка зданія центральнаго полищейскато покоя для душевно-больныхт вт Москв состоялась 23 августа. Покой устраивается, по почину и. п. Московскаго оберъ-полпіймейстера, во цвор бо Іречистенскаго дешо. Докой состужается на 40 кроватей. Зданіе строится каменное вт два этажа с'ь полуподвальнымт помшеніемт. По. стройка покоя закончитея въ будущемт году.

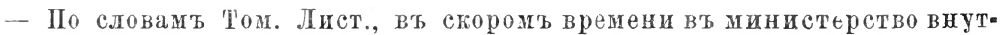
ренних дыль будеть представлен'ь мистной администраціей проектный плань больницы для душевно-больныхт. Судя по этому плану, названная больница должна будеть занять въ Сибири въ числь другихт этого рода больнщц шервенствующее мьсто: шри ней будуть отдыльныл помьњенія для иителлигентныхь больныхь и для простонародья, для непөкойныхь, для хроншковт, для нечистоплотных' и т. д.; для каждой изт перечисленныхт категорій больныхь будеть разведент отдыльый садъ; затьит, въ самомь вданіи общіе залы для гуданя; кромь того, огороды и мастерскія; для духовныхъ потребностей выздоравливающихт больныхъ-перковь, отдьльный заль для библіотеки и т. д. Стоимость больницы, вместь съ баракомъ для заразныхъ больныхъ, исчислена въ 350000 руб.

- Въ С.-Петербургскомъ обществы шсихіатровт возбуждень вопрост 0 необходимости обученія низшаго персонала служапихт вь психіатрическихт заведеніяхъ уходу за душевно-больными. Въ виду неотложности и важности этого вопроса 0бществом уже вырабогант проекть, согласно которому во всыхь психіатрических заведеніяхь предполагается ввести си- 
стематическое обученіе служапихт и сидылокт уходу за больными. В' ирограмму занятій шредполагается ввести: 1) өсновы больничнаго призрная и устройство больничной службы; 2) практическія свйьнія о стрееніи и от-

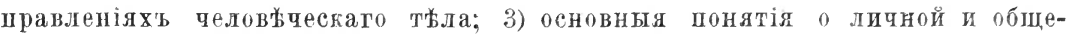
ственной гигіент; 4) уходт при обпих'ь бользняхт; 5) подача первсй по-

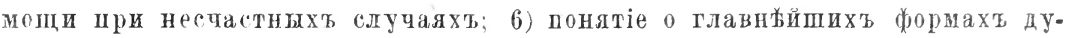
шөвныхь бользней и 7) уходь за больными.-Ю. Р. М. Г.

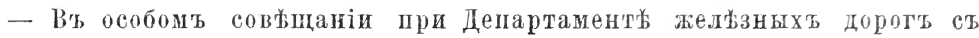
участіемь приглашенныхь врачей быль недавно подергнуть обсужденію випрось о сравнительно частой забольнаемости желњзнодорожныхь служапих'ь шеихическимь разстройствон' и о призрвпіи дупевно-больныхь. Совнщаніе пришло кт заключенію о настоятельной необходимости устройства центральнаго жельзно-дорожнаго дома или колоніи для прдзрьнія душевнобольныхт жельзно-дорожныхь служащихт и членовт ихъ семейстьъ. Вошрес этоть по распоряженію министра путей сочбщенія переданъ на разсмотрыніе общаго съьзда представителей русскихь жельзных дорогь. F. Р. M. $Г$.

--- Вь Больниць Николая Чудотворца въ Петербурге больной, страдавпій наростающим прогрессивным параличемъ, умеръ оть побоевъ служителя. При вскрысіи найдент переломт 10 реберь. Покойный был' доставлень вт больнищу уже настольго слабымъ и истощеннымт, что его тотчаст же приплось помьстить въ лазареть, гды, спустя нысколько времени, онъ умерт. Вскрытіе показало переломт щьлаго рада реберъ. Немедленно было сообщено о найденном' административнымъ и судебным властям, такъ что векрытіе было докончено полицейским враченъ въ присутствіи судебнаго сльдователя. Разсльдованіе ноказало, что въ ночь смерти больного в'ь отдыленіи лазарета, гды онь находилея, дежурили 4 служителя и въ числь ихъ Волковъ, наказаниы за нбсколько дней передъ тыль за грубое обращеніе съ однимъ изъ больныхъ. ІІдозрьніе пало на Волкова, отрищавшаго свою вину. Дознано, что утромь 3-го іюля Волковъ перемьниль свое платье, оказавпееся совсьм изорваннымь, и на львочь кольны была найдена ссадина, находивпаяся на уровны қрая кровати. Наконець, другой больной, помддавшійся рядомъ и обладающій, по мньнію пользующихъ его врачей, цостаточно яснымъ сознаніем', заявиль, что покойный въ 11 часовт ночи, вскочивь съ кровати, удариль Волкова, который, разсердивпись, броснль больного поперект гровати и сталь его мять. (Врачъ).

- На VI съљзд⿻ для борьбы сь злоупотребленіемт спиртными напиткачи, который собирался въ Брюссель съ 30 августа по 5 сентября, всь вопросы были раздылены на 4 отдыза: 1) загонодательство, соціологія п политическая әкономія; 2) восшитаніе и обученіе; 3) врачебная сторона и тигіена; 4) противоалкогольная пропаганда, участіе женщинъ въ борьбъ съ альотолизмомь. (Врачг).

- Вь Hospice Générale de St-Jacque въ Nantes`t пропзопель печальный случай: падучный, на котораго надыли смирительную рубашку, умеръ, повидимому, именно всдьдствіе этого обстоятельства. (Врамг). 
- 17 іюля д-ръ Mеrson, служащій в' Jinll Borongh Asylnm, получил'ь оть одного из' душевно-больныхт такой сильный ударт, палкой шо затылку, что вналт в' безнамятство, вт котором' и пробыль ньеколько часовт. Въ теченіе нисколькихт дней оцасались даже за жизнь пострадавшаго, но теперь онт уже поправляетсл. (Врачг).

- Ревизія Херсонской земской психіатрической больнищы не нашла никаких' злоупотребленій. Завъдующій этой больницей, д-р'ь Гинзбургъ. ПІикь снова встуииль въ отправленіе своихт облзанностей по управленію ег. - H. P. M. $Г$

- 25.го минувтаго маят состоллось отврытіе Вннницкой окружной Лечебницы в' прнсутствіи начальника 10го-Занаднаго края, губернаторовъ трехт губерній края и иногочисленныхь высокоцоставленных гостей. На торжество отпрытія были притлашены также нйоторые профессора университета св. Владиміра, врачебные мнспекторы трехв губерній Ю0го-Западнагө края и врачи, завыдующіе въ нихь психіатрическии заведеніями. Торжество началось освяшеніемь церкви, которое совершаль мыстный преосвященный Ириней, послт чего посльдовало освященіе и осмотры дыстебницы. Затьмь состоялея обьдъ, на котороиь ироизнесены были ревчи начальником' грая, графомь А. II. Игнатьевым, директором's диячебниц

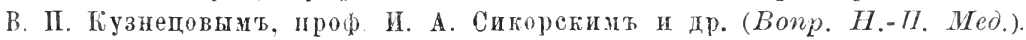

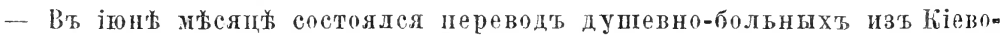
Кирцлловюкой больницы в' Винницкую 0 кружную Л为чебницу. Всего пока изъ Кцрилловекой больницы переведено въ Винницу 80 больных'ь (ә0 мужчинь и 30 женщинъ); кром того туда же переведено изь житоміра и Каменещт-Подольска 70 больныхь. Штаты для Винницкой Јбчебницы на 1897 и 1898 г. утвержднны на 450 кроватей, но остальныя 300 кроватей будуть

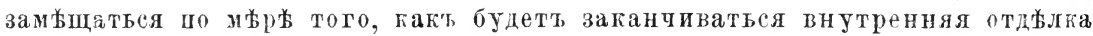
.Јичебиицы. (Воир. Н.-II. Мед.).

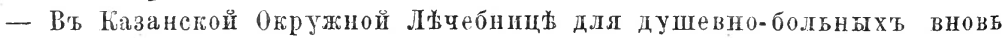
учреждено второе мйсто сверхштатнаго ординатора сь содержаніем'ь из' спеціальныхъ средств'ь Лвчебнищы.

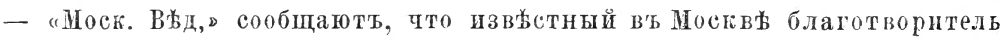
A. С. Капиовь, недавно умершій, завъцаль 100000 руб. на дыла благотворенія. Душеприкащики покойнаго совмьстно ст городеким головою княземь В М. Голицыным, согласно иредоставленному имъ завыпдателемь праву, распредьлили капиталь сльдующимъ образом'ь: 1) 10000 руб. въ пользу Яузскаго городского папечительста о бъдныхт, 2) 8000 руб.-в'ь тородскую А ль к с вй дачь, на учрежданіе кровати именд А. С. Капцова п 3) 82.000 руб.на постройку особаго корпуса цри той же Больниц имени А. С. Капцова приблизительно на 70-80 кроватей. Городская Дума, принявт пожертвованіе, постановила ходатайствовать о просвоеніи инени А. С. Каппова вновь учреждаемой кровати въ Городской психіатрической Больниц'ь п проектирванному корпусу при той же Больниц为. 